\title{
Analysis on the Implications of Basic English Lessons Education Reform for College English Education
}

\author{
Jing Xin ${ }^{1}$ \\ ${ }^{1}$ Wuhan Institute of Technology, Wuhan, 430200
}

54892713@163.com

Keywords: Basic English; Education Reform; College English Education

\begin{abstract}
Current English education exists some problems, leading to English proficiency of university graduates unable to meet the requirements of society and the job market. In this context, this paper analyzes the current situation of English proficiency of college students, and made in the context of university English education reform, university teachers to improve students' English proficiency should be integrated in curriculum, teaching mode, teaching methods, learning styles and evaluation methods and other aspects of efforts to improve the English proficiency of university graduates. With the arrival of the era of economic globalization.
\end{abstract}

\section{Introduction}

Our basic English education has always been famous for exam-oriented education, but also because "Gaofendineng" by the criticism. But the decision of the State Council on the decision to promote quality education and on basic education reform and development driven, after several years of preparation, the new curriculum standard was finally issued. The new standard is divided into four sections, nine levels, across elementary, middle and high school three levels, including the guiding ideology, curriculum goals, content standards, the implementation of the recommendations and other parts. Although some places still unsatisfactory, but the standard reflected the novelty made us sit up, but also to college English reform provided a lot of inspiration. These "new" in the author's opinion can be summarized in three points: build capacity, improve quality and overall development.

In terms of capacity-building, the new standard at the outset, is to "over-emphasis on curriculum reform English grammar and vocabulary knowledge to explain and teach," the tendency to strengthen "the students' ability to use actual language culture." In the description of each level requirements when the new standard does not set at all levels of the specific rules of grammar, vocabulary, but to see whether the students "can [in English] to do." In eight (high school graduation), for example, the new standard requires students to "be able to familiar topics with English-speaking people were more natural communication. Can leave a comment on the content of the opinion orally or in written materials. Can write coherent and structure complete essay. to independent planning, organization and implementation of language practice can effectively use a variety of educational resources to acquire and process information networks "and so on. The new standard text 20001 thousand words, which "can" appeared 400 times, the designer's intentions can be seen by. In improving the quality, the new standard describes the contents of language skills, although not so specific paper also mentions only seven times, but their awareness has risen to the height of "Citizen Education", reflecting the requirements of the times. The new standard recognizes that learning English is not only a process of obtaining knowledge and skills, but also a "sharpen the will, strive to expand their horizons and enrich life experiences, develop thinking skills, personality development and improve the process of the humanities," and requires students not only to "inherit and carry forward the fine tradition and the revolutionary tradition of the Chinese nation", but also learn to "take the attitude of respect and tolerance for other cultures." To this end, the new standard dedicated to the process of learning English at different stages of "cultural consciousness" put forward specific requirements. 


\section{College English Teaching Reform Requirements}

College English teaching goal is to develop students' English language proficiency, especially in listening and speaking ability, enhance their self-learning ability and can be applied to real life English. College English teaching requirements include three levels, namely the general requirements, higher demand and higher requirements. These are non-English majors colleges and universities through study and practice English at the university level should be selected to achieve the standard. In accordance with the requirements of college English teaching reform, curriculum design should take full account of English listening and speaking skills, and given enough hours and credits; extensive use of computer information technology, development and construction of various computer and network courses provide students with a good language learning environment. At the same time, to improve the teacher taught mainly single teaching mode. The new model should be based on modern information technology, especially in the network technology to support teaching and learning English can make an unlimited time and space to a certain extent, toward personalization and self-learning direction.

\section{College English Teaching Problems}

(A) the limitations of the classroom. The new curriculum requirements for classroom teaching is not restricted by time and space, but the traditional concept of teaching teachers and students are limited to be completed within 45 minutes of a lesson and classroom beyond these seem to violate the rules. (B) the problems in teaching. Traditional teaching teachers teach knowledge, the students passively absorb knowledge-based acceptance. Teachers just keep teaching in the classroom, little attention to whether students really grasp the knowledge. Teachers pay more attention to the structure of the system of knowledge, logic and rigor, little attention to interesting and innovative knowledge. Classroom teachers do not realize the true subject is the study of high school students. (C) the concept of student learning problems. Since the adaptation of the traditional teaching model, students in the classroom just passively wait for teachers to teach their own knowledge. Great danger of this passive learning, students will produce psychological dependence, and almost not questioned knowledge, Lenovo can not find the problem, solve problems, their creative thinking and ability to be cured. (D) convergence of teaching basic education reform issues. New curriculum reform of basic education has largely changed the traditional teaching mode and evaluation mode. College English teaching reform to keep pace with the pace? It has been adapted to the new curriculum after students are accepted into college or the traditional mode of teaching the new curriculum and teaching model of convergence? (E) teaching evaluation whether they can adapt teaching reform issues. The new basic education curriculum has changed the previous single evaluation model, focusing on formative assessment and diversification, diversification of evaluation. University of relatively high school curriculum evaluation

To loose a lot. But it should also pay attention to whether they can adapt education teaching evaluation reform. Teaching Evaluation is designed not only to give students a relaxed learning environment and atmosphere, even more important is to encourage students through effective diversification of the evaluation model is more effective learning, to make it more comprehensive physical and mental development.

\section{Inspiration of University English Education}

Implications for schools. First, should the times. In order to meet the 21st century international mutual integration and socialization of large-scale development and intercultural school should advance with the times. Modern science and technology innovation, the content of school textbooks should be constantly updated. Second, college English teaching reform should be closely co-ordinated teaching reform of basic education. The new basic education curriculum has been vigorously carried out, and achieved remarkable results and achievements. Then, students trained at the University of New Curriculum into the classroom, whether to change the traditional college 
classroom teaching mode? Therefore, college English teaching reform is imperative to closely co-ordinated teaching reform of basic education. College English teaching should be more prominent subjectivity of students, give students more free time to access to information, identify problems, analyze and solve problems. Third, reform the evaluation system. Previous school evaluation means is obtained by blunt digital exam to prove that the subjects of learning. Although the score does not represent the student's ability, but was able to decide scores of teachers and schools, and other students of the students evaluated. In recent years, the evaluation of courses, colleges and universities have also been many reforms, for example, a combination of required courses and electives, hierarchical evaluation and score evaluation of the combination; taken in the oral evaluation tools, practical, independent creations, papers, etc. different forms. If these forms can stick to it, it will bring a relaxed environment for learning and development of students, improve students' creative thinking and ability to benefit.

Implications for teachers. Teachers are dominant. First, teachers in the teaching process should not only continue to reflect on their own teaching, identify problems and conduct research and improve their teaching and research; students should study the past, present and future, the students learn the reality of the situation and Professional closely linked, and attention to student growth and professional development. Second, teachers should continue to study the theory of knowledge and expertise at the same time improve the professional ethics of the times, to keep up with the pace of development. Third, teachers should put the classroom to the students, the students should learn self-study, teachers play a guiding and enlightening. And how to guide students to effectively learn what is beneficial to teaching methods to develop students' creative thinking is a matter of teachers should focus on consideration. There are several methods. A task type is teaching methods. TaskbasedTeaching Method is a requirement of basic education English teaching strategies in the creation of good language teaching scenarios for students to ask tasks around tasks and questions to guide students to identify and solve problems. This not only facilitates the training of students 'self-learning ability, so that students learning objectives more clearly, more conducive to expand students' creative thinking, improve the ability of students. The process of cooperation in the group can also provide students with more opportunities to discuss issues and practice speaking in English. Second, the students cooperation and competitiveness. Scenarios for different teaching creation in teaching, use of teaching methods, students can develop cooperation and competitiveness. Such as task-based teaching methods, students make learning task division team, as a group cooperative learning, gather materials, to discuss common experimental confirmation, draw conclusions. Between the team and the team elected to complete the task by the game's best in a group. Cooperation and competition not only can develop emotional communication between students, to enable students to establish a correct concept of emotions, students can also conscious cooperation and legitimate competition. Such activities may seem simple, in fact, focus on tasks that teachers set is scientific, feasible and meaningful, can guide students to organize activities in an orderly manner, the ability of teachers to make a scientific evaluation of the conclusions and creative expand. The third is to establish a scientific and reasonable evaluation method. We should establish a sound scientific approach to the evaluation of students. Change the past to focus only on scores, the results of the evaluation form. Based on "College English Curriculum Requirements" requirements, the university should pay more attention to improve students' English listening and speaking proficiency, and accordingly may be inclined to evaluate these aspects. For example, speaking classes, writing classes, etc. can be set oral, written in the form of papers or English novels, give full play to the students' enthusiasm and innovative thinking of. In short, teachers should try to create the appraisal methods to improve students' listening and speaking for the purpose.

\section{Conclusion}

Our university English education is now at a crossroads. Faced with the challenges, we should not "prevent sticking", but should seriously reflect on, look for their own shortcomings, commitment to reform, improve students' proficiency. 


\section{References}

[1] Brookfield, Stephen D.Developingcritical thinkers: Challenging adults to explorealternative ways ofthinking and acting.SanFrancisco: JosseyBass, 1987.

[2] Hall, Robert A.Jr.Pidgin and Cre-ole Languages .Ithaca: Cornell Univer-sityPress, 1966.

[3] Cao Yanyan. Predicament and Countermeasures of College English Education Reform Reality. College English (Academic Edition), 2013 (02).

[4] Zhang Yao school. Strengthening Practical English Teaching to Improve Students' English Language Competence. Chinese higher education, 2002 (08). 